\title{
Analysis of Prophylactic Parameters and the Relative Cut-off Values for Predicting Stromal Herpes Simplex Keratitis Recurrence
}

Feifei Huang

Eye \& ENT Hospital of Fudan University

Zhujian Wang

Eye \& ENT Hospital of Fudan University

Wenjun Cao

Eye \& ENT Hospital of Fudan University

Chunhong Liu

Eye \& ENT Hospital of Fudan University

Chaoran Zhang ( $\nabla$ zhangchaoran@hotmail.com )

Eye \& ENT Hospital of Fudan University

\section{Research Article}

Keywords: Stromal HSK, recurrence, Tear HSV-slgA, Tear HSV-DNA

Posted Date: February 3rd, 2022

DOI: https://doi.org/10.21203/rs.3.rs-1159580/v1

License: (9) This work is licensed under a Creative Commons Attribution 4.0 International License. Read Full License 


\section{Abstract}

Background: To assess the potential values of clinical characters, tear HSV-slgA and tear HSV-DNA for prediction of stromal HSK recurrence.

Methods: Tears and serum IgG/IgM/IgA from 187 stromal HSK patients were collected. All the 187 tear samples serum samples were tested by ELISA for slgA/ IgG/lgM/lgA. 146 tear samples were also tested by PCR for tear HSV-DNA. Subsequent follow-up time for monitoring recurrence was performed on all the 187 patients for 2 to 55 months.

Results: The positive rate of tear HSV-slgA was 36.90\% (69/187), while for tear HSV-DNA, the positive rate was $10.96 \%$ (16/146). Totally 29 of the 187 participants experienced recurrence (15.51\%). Previous episodes, tear HSV-slgA-positive and tear HSV-DNA-positive patients had significantly shorter relapsefree survival $(P<0.01, P<0.01$ and $P=0.0123$ respectively). Patients combined univariate and multivariate analysis together, only tear HSV-slgA was the factor for predicting the risk of herpes keratitis recurrence $(\mathrm{HR}=2.768,95 \% \mathrm{Cl}=1.148-6.674, \mathrm{p}=0.023)$. By using Youden index, the concentration of tear HSV-slgA >= $22.34 \mathrm{U} / \mathrm{ul}$ indicated a higher risks for relapse (sensitivity $=79.31 \%$, specificity $=63.92 \%$, Youden index $=0.43)$.

Conclusions: Though episode, tear HSV-slgA and tear HSV-DNA all have high correlation with recurrent herpes keratitis, only tear HSV-slgA is considered to be the most appropriated candidate for predicting the risk of recrudescent HSK. As tear HSV-slgA $>=22.34 \mathrm{U} / \mathrm{ul}$, the risks for recurrence will be much higher. It is might be an appropriate cut-off value for predicting recurrence.

\section{Background}

Herpes simplex keratitis (HSK) is the leading cause of infectious corneal blindness in developed countries [1]. The costs of treatment for HSK are in the tens of millions spent annually in the US alone. Stromal HSK is characterized by high recurrence which eventually leads to corneal thinning, neovascularization, and permanent visual loss [2]. The Herpes Eye Disease Study (HEDS) has shown that taking oral antiviral drugs is a mainstream prophylactic method to prevent the recurrence $[3,4]$. However, a systematic review on the HEDS has reported that the efficiency of various methods to prevent HSK recurrence, including oral acyclovir, remains debatable [5].

Tear secretory $\lg \mathrm{A}(\mathrm{s} \lg \mathrm{A})$ is the major tear immunoglobulin and an essential immune defense factor against infection of ocular disease, and it rarely can be transferred from blood to tears. Tear HSV-slgA is proved an adjunct to HSK diagnosis [6]. Our previous study has found that tear HSV-slgA could be a potential prognostic parameter for the recurrence of stromal HSK [7].

Detecting tear HSV-DNA with Polymerase chain reaction (PCR) is believed a sensitive and rapid auxiliary diagnosis for HSK, and the rate of positivity depends on the subgroup of HSK, previous oral anti-viral treatment, and the virus loading in specimen [8]. Our previous study has compared the differential 
diagnostic values for stromal HSK by tear HSV-sIgA (ELISA), tear HSV-DNA (PCR), and the combination. The results have shown that the diagnostic efficiency of tear HSV-slgA is higher than that of tear HSVDNA [9]. However, until now the potential relationship of tear HSV-DNA with stromal HSK recurrence remains unknown.

The aim of our research is to analysis the possible correlation of tear HSV-DNA with stromal HSK recurrence, and to evaluate the prognostic efficiency of tear HSV-sigA and tear HSV-DNA.

\section{Materials And Methods}

\section{Patients}

187 patients attending Eye Ear Nose and Throat Hospital, Fudan University, diagnosed with acute stromal HSK by experienced ophthalmologist during Sep 2011to Jan 2016 were enrolled in this study. The mean age was $51.51 \pm 13.00$, with a range from 20 to 85 . All the patients involved in this research were not taken any kind of oral antiviral medications for treat or prophylactic purpose during the whole process of our study. The out-patient follow-up time ranged from 2 to 55 months. All involved subjects were monitored for the recurrence of HSK by the same ophthalmologist based on the clinical features using slit lamp. The treatment for all the patients included topical antiviral eye-drops /ointment, glucocorticoid eye-drops and/or $0.5 \%$ cyclosporine A eye-drops. Ethics approval for the use of human subjects was obtained from the research ethics committee of EYE and ENT hospital, and informed consent was obtained from each patient.

\section{Samples}

Tear samples from the lower fornices of both eyes were collected into capillary tubes then expelled into Eppendorf tubes, respectively. The volume of each sample was usually 5 to $20 \mathrm{uL}$. Anesthesia was not used during the process. All the specimens were transported immediately and stored at $-20^{\circ} \mathrm{C}$ until processed [9].

\section{Enzyme-Linked Immunosorbent Assays}

Serum and Tear specimens were assayed by enzymelinked immunosorbent assay (Virion/Serion classic HSV 1+2 lgG/lgM/IgA; order number ESR105G, ESR105M, ESR105A, Würzburg, Germany). According to the manufacturer's instructions, only Serion reagents were used for the test procedure. Microtest plates were coated with antigens, which constituted the solid phase. Patient samples were added to the plates, and any antibodies specific for antigen present would bind to the solid phase. After dilution with phosphate-buffered saline, samples and standard sera were pipetted into the microtest wells, which were incubated for 60 minutes at $37^{\circ} \mathrm{C}$ in moist chambers, then thoroughly washed four times with washing solution by automated washer. $\lg / \operatorname{lgM} / \lg A$ conjugates were added to the appropriate wells and incubated for another 30 minutes, then washed as before. Every well was then covered with substrate solution followed by 30 minutes incubation. Finally, stopping solution was used to stop the reaction. The 
microplate reader (Sunrise-Basic, Tecan, Austria) was used to read the extinctions at $620 \mathrm{~nm}$. Values were considered positive if sample/cutoff (s/co) values were greater than 1 . Antibody activities in units per milliliter were determined from the standard curve with the corrected values [9].

\section{Real-time polymerase chain reaction}

The detection of tear HSV-DNA was carried out using the Liferiver HSV 1+2RT-PCR kit (Shanghai, China). Reactions were set up and performed according to the manufacturer's instructions, and were executed by the vitro medical diagnostic device intended for use on the Loche 480 instrument. All reactions were performed in a total volume of $40 \mathrm{ul}$. The reaction conditions were as follows: pre-denaturation at $37^{\circ} \mathrm{C}$ for $5 \mathrm{~min}$, followed by 40 cycles of denaturation at $94^{\circ} \mathrm{C}$ for $1 \mathrm{~min}$, annealing at $95^{\circ} \mathrm{C}$ for $5 \mathrm{~s}$, and extension at $60^{\circ} \mathrm{C}$ for 30 s [9].

\section{Statistical analysis}

Statistical analysis was carried out by using Statistical Package for Social Sciences software (SPSS 21.0 for windows, IBM), and a $p<0.05$ was considered statistically significant. Data were presented as mean \pm SD. Univariate and multivariate analysis were based on the Cox proportional hazard regression model. The relationship between the relapse and the slgA positivity was analyzed by Kaplan-Meier survival curves and the log-rank test. Receiver operator characteristic curve (ROC) analysis was used for evaluating the predictive power, and Youden index was used for cut-off value evaluation.

\section{Results}

Positive and negative results were determined according to the following criteria: specimens with $\geq 30$ copies/sample of HSV DNA and for HSV-slgA s/co $\geq 1$ were deemed positive.

In total, 187 stromal HSK patients were enrolled in this study. Among the 187 cases, 139 presented with epithelial defects. The positive rates of serum HSV specific IgG, IgM, and IgA were $100 \%, 1.60 \%(3 / 187)$, and $51.87 \%$ (97/187). All the 187 patients were tested for tear HSV-slgA, and the positive rate was $36.90 \%$ $(69 / 187)$ in infected eyes. For the 139 patients with epithelial defects, 60 (43.17\%) were also HSV-slgA positive. 146 stromal HSK patients were detected for tear HSV-DNA levels. The positive rate for infected eyes was $10.96 \%$ (16/146). Fifteen of the 110 fluorescence staining positive patients $(13.64 \%)$ were detected as HSV-DNA.

By the time of analysis, totally 29 of the 187 stromal HSK patients recurred (15.51\%). Recurrence had occurred in 21 of 129 male patients (16.28\%), while for 58 females, 8 recurred (13.8\%). The clinical characteristics of the patients and the correlation with relapse are summarized in Table 1. For 69 tear HSV-slgA positive patients, 20 experienced recurrence. Fifteen of the 20 recurrent patients were also detected for tear HSV-DNA, and four showed HSV-DNA positive. 
Table 1

The clinical characteristics of the patients and the correlation with relapse

\begin{tabular}{|c|c|c|c|c|c|c|}
\hline \multicolumn{2}{|c|}{ Clinical characteristics } & \multirow{3}{*}{$\begin{array}{l}\text { No } \\
43\end{array}$} & \multirow{2}{*}{\multicolumn{2}{|c|}{$\begin{array}{l}\text { Sick eye } \\
\text { Recurrence No recurrence }\end{array}$}} & \multirow{4}{*}{$\begin{array}{l}\chi^{2} \\
0.025\end{array}$} & \multirow{4}{*}{$\begin{array}{l}p \\
0.874\end{array}$} \\
\hline & & & & & & \\
\hline \multirow[t]{2}{*}{ Age } & $\leq 40$ & & 7 & 36 & & \\
\hline & $>40$ & 144 & 22 & 122 & & \\
\hline \multirow[t]{2}{*}{ Sex } & Male & 129 & 21 & 108 & \multirow[t]{2}{*}{0.189} & \multirow[t]{2}{*}{0.66} \\
\hline & Female & 58 & 8 & 50 & & \\
\hline \multirow[t]{2}{*}{ Episode } & First time & 68 & 2 & 66 & \multirow[t]{2}{*}{12.879} & \multirow[t]{2}{*}{0.000} \\
\hline & Recurrence & 119 & 27 & 92 & & \\
\hline \multirow[t]{2}{*}{$\mathrm{FL}$} & + & 139 & 24 & 115 & \multirow[t]{2}{*}{1.278} & \multirow[t]{2}{*}{0.25} \\
\hline & - & 48 & 5 & 43 & & \\
\hline \multirow[t]{2}{*}{ KP } & + & 75 & 11 & 64 & \multirow[t]{2}{*}{0.068} & \multirow[t]{2}{*}{0.795} \\
\hline & - & 112 & 18 & 94 & & \\
\hline \multirow[t]{2}{*}{ Serum HSV-lgG } & + & 187 & 29 & 158 & \multirow[t]{2}{*}{ NA } & \multirow[t]{2}{*}{ NA } \\
\hline & - & 0 & 0 & 0 & & \\
\hline \multirow[t]{2}{*}{ Serum HSV-IgM } & + & 3 & 1 & 2 & \multirow[t]{2}{*}{0.595} & \multirow[t]{2}{*}{0.441} \\
\hline & - & 184 & 28 & 156 & & \\
\hline \multirow[t]{2}{*}{ Serum HSV-lgA } & + & 97 & 14 & 83 & \multirow[t]{2}{*}{0.187} & \multirow[t]{2}{*}{0.673} \\
\hline & - & 90 & 15 & 75 & & \\
\hline \multirow[t]{2}{*}{ Tear HSV-slgA } & + & 69 & 20 & 49 & \multirow[t]{2}{*}{15.158} & \multirow[t]{2}{*}{0.000} \\
\hline & - & 118 & 9 & 109 & & \\
\hline \multirow[t]{2}{*}{ Tear HSV-DNA } & + & 16 & 5 & 11 & \multirow[t]{2}{*}{2.072} & \multirow[t]{2}{*}{0.150} \\
\hline & - & 130 & 18 & 112 & & \\
\hline
\end{tabular}

In univariate analysis, episodes, tear HSV-sIgA positivity and tear HSV-DNA were three factors for predicting the risk of stromal HSK recurrence (Episodes: $\mathrm{HR}=8.770,95 \% \mathrm{Cl}=2.085-36.889, \mathrm{P}=0.003$; tear HSV-slgA: $\mathrm{HR}=4.310,95 \% \mathrm{Cl}=1.961-9.472, \mathrm{P}=0.000$; tear HSV-DNA: $\mathrm{HR}=3.347,95 \% \mathrm{Cl}=0.238-9.047$, 
$\mathrm{p}=0.017$ ) (Table 2). Multivariate analysis showed that only tear HSV-slgA was the factor for predicting the risk of herpes keratitis recurrence $(\mathrm{HR}=2.768,95 \% \mathrm{Cl}=1.148-6.674, \mathrm{p}=0.023)$ (Table 3$)$.

Table 2

Univariate cox proportional regression analysis of factors associated with recurrence

\begin{tabular}{|c|c|c|}
\hline \multirow[t]{2}{*}{ Variable } & \multicolumn{2}{|l|}{ Univariate Analysis } \\
\hline & $\mathrm{HR} \square 95 \% \mathrm{Cl}[$ & $p$ \\
\hline Age $>40$ vs. $\leq 40$ & $1.007(0.430-2.357)$ & 0.988 \\
\hline Sex male vs. female & $0.827(0.366-1.866)$ & 0.647 \\
\hline $\begin{array}{l}\text { Episode } \\
\text { first time vs. recurrence }\end{array}$ & $8.770(2.085-36.889)$ & 0.003 \\
\hline Category lesion in stroma and epithelium vs. lesion in stroma & $1.704(0.650-4.466)$ & 0.279 \\
\hline Serum HSV-IgG (positive vs.negative) & NA & NA \\
\hline Serum HSV-IgM (positive vs. negative) & $2.556(0.348-18.801)$ & 0.357 \\
\hline Serum HSV-IgA (positive vs. negative) & $0.835(0.403-1.730)$ & 0.628 \\
\hline Tear HSV-slgA (positive vs.negative) & $4.310(1.961-9.472)$ & 0.000 \\
\hline Tear HSV-DNA (positive vs.negative) & $3.347(0.238-9.047)$ & 0.017 \\
\hline \multicolumn{3}{|c|}{$\begin{array}{l}\text { Bold indicates the statistical significance of tear slgA in predicting the risk of herpes keratitis } \\
\text { recurrence }(p<0.05)\end{array}$} \\
\hline $\mathrm{Cl}$, confidence interval; HR, hazard ratio; NA, not applicable; sl & tory immunoglobulin. & \\
\hline
\end{tabular}

Table 3

Multivariate cox proportional regression analysis of factors associated with recurrence

\begin{tabular}{|lll|}
\hline Variable & Multivariate Analysis & \\
\cline { 2 - 3 } & HR(95\% Cl) & $\mathbf{p}$ \\
\hline Episode(first time vs. recurrence) & $282287.270(0.000-9.335)$ & 0.937 \\
\hline Tear HSV-slgA (positive vs.negative) & $2.768(1.148-6.674)$ & $\mathbf{0 . 0 2 3}$ \\
\hline Tear HSV-DNA (positive vs.negative) & $2.632(0.948-7.313)$ & 0.063 \\
\hline $\begin{array}{l}\text { The three clinic-pathologic variables were adopted for their prognostic significance by multivariate } \\
\text { analyses. }\end{array}$ & \\
\hline
\end{tabular}


Kaplan-Meier curve showed that both tear HSV-slgA and tear HSV-DNA positive patients had significantly shorter relapse-free survival (tear HSV-slgA: $\mathrm{P}<0.01$, Hazard ration=4.292, 95\% Cl=2.194-10.19; tear HSVDNA: $\mathrm{P}=0.0123, \mathrm{HR}=3.291,95 \% \mathrm{Cl}=1.530-32.33$ ) (Figure 1A, 1B). For those patients who had a history of recurrence, they also had shorter relapse-free survival $(\mathrm{P}<0.01, \mathrm{HR}=8.757,95 \% \mathrm{Cl}=1.853-8.222)$ (Figure1C). The area under the ROC curve (AUC) for episode was 0.679 , with a sensitive of 1 and a specificity of $0.358(p=0.007,95 \% \mathrm{Cl}=0.582-0.775)$; tear HSV-slgA had the biggest AUC, which was $0.760(P=0.001$, $95 \% \mathrm{Cl}=0.693-0.820)$. The AUC for tear HSV-DNA was $0.569(\mathrm{P}=0.147,95 \% \mathrm{Cl}=0.484-0.650)$. The HSV-slgA and HSV-DNA cut-off value for predicting HSK recurrence was $22.34 \mathrm{U} / \mathrm{ul}$ (sensitivity $=79.31 \%$, specificity $=63.92 \%$, highest Youden index $=0.43$ ) and 208370 (sensitivity $=17.39 \%$, specificity $=98.37 \%$, highest Youden index=0.16) (Figure 2).

\section{Discussion}

HSK is a common infection of the cornea caused by herpes simplex virus. Relapsing and recurring stromal herpes keratitis significantly increases the risk of corneal neovascularization and blindness [10]. Reactivation of the HSV in trigeminal ganglion can be attributed to stress, trauma, and ultraviolet radiation [11,12]. The risk of recurrence is $20 \%$ by 2 years, $40 \%$ by 5 years, and $67 \%$ by 7 years [13]. The Herpetic Eye Disease Study (HEDS) demonstrated that long-term antiviral prophylaxis with oral acyclovir significantly reduced the recurrence $[3,4]$. However, prophylaxis fails in a great number of patients. Management of these patients who experience relapse despite antiviral prophylactic therapy is challenging. These relapse may be due to viral resistance, poor drug absorption, or poor patient compliance [14]. In addition, long-time oral antiviral therapy is an expensive preventive strategy. The cost for prophylactic acyclovir group is nearly as eight times as controls [15].

Our previous study tested the tear HSV-slgA concentrations of 41 stromal HSK and suggested that the levels of tear slgA could be a potential prognostic parameter for the recurrence of stromal HSK [7]. This present research had enlarged the samples and prolonged the follow-up time, and the results showed that in univariate analysis tear HSV-slgA, tear HSV-DNA and the episodes were potential risk factors for HSK recurrence. However, as these three potential risk factors were analysed together using multivatiate analysis, only tear HSV-sIgA still remained a significant risk factor. It has been demonstrated that the HSV-1 in the tears of recurrent HSK patients is highly likely to harbor genotypically resistant viruses. We postulated that these subtypes of viruses might cause severe and long-lasting ocular immune response. And slgA, as the major defense factor against ocular infection, can be influenced a lot.

The Kaplan-Meier results of our study observed that those patients with tear HSV-DNA positive seemed to have a higher risk of relapse, however, for both multivariate analysis and ROC curve tear HSV-DNA was not an efficient parameter for predicting recrudescent herpes keratitis (multivariate analysis: $p=0.063$; ROC curve: $P=0.147$ ). The relative low positive rate for tear HSV-DNA tested by PCR might explain this condition. While PCR of virus collected from tears was more sensitive than both viral isolation and immunofluorescence from tears, it was significantly less sensitive than corneal scraping $(P<0.0005) .{ }^{16}$ Also, the timing of testing tear film could influence the results, as viral loads in tears decrease a lot after 
day 11 of illness which could have further increased false negatives [16]. Some stromal HSK patients did not manifest any epithelial defects, which also affected the tear HSV-DNA positivity, because epithelial defects and corneal ulcers mean more virus loads in the tears. Once the concentration is higher than 105 copies/ml, the tear positive rate will increase [17]. So the patients with tear HSV-DNA positive may have a higher risk of recurrence than those with tear HSV-DNA negative, but as the positive rate is relative low in our study, the efficiency of tear HSV-DNA for predicting relapse is not high.

The HEDS suggested that patients with previous episodes of stromal keratitis (especially those with numerous recurrence history) were at higher risk of further recurrence [18]. By contrast, a previous Korean study found that past ocular history, systemic disease, or HSK subtype did not associate significantly with HSK recurrence [19]. In our present research, the episodes seemed to be a potential risk factor for stromal HSK recurrence using univariate analysis. However, the results of combination analysis of episodes, tear HSV-slgA and tear HSV-DNA indicated that episodes did not associated with relapse significantly $(P=0.937)$.

Overall, only the concentration of tear HSV-slgA is the best parameter for relapse prediction. It is of great vital to evaluate a proper HSV-sIgA cut-off value for predicting recurrence. Youden index can describe the accuracy of a test. We found that when the concentration of slgA was $22.34 \mathrm{U} / \mathrm{ul}$, it had the highest Youden index 0.43 (sensitivity $=79.31 \%$, specificity $=63.92 \%$ ). So, for the patients with tear HSV-slgA concentration $>=22.34 \mathrm{U} / \mathrm{ul}$, they may have a higher risks for recrudescent HSK.

\section{Conclusions}

This present study analyses the correlations of the clinical characters and relative laboratory testing of stromal HSK with recurrence risks. Though episode, tear HSV-slgA and tear HSV-DNA all have high correlation of recurrent herpes keratitis, only tear HSV-slgA is considered to be the most appropriated candidate for predicting the risk of recrudescent HSK. And the cut-off value of HSK-slgA concentration for predicting the recurrence risk is $22.34 \mathrm{U} / \mathrm{ul}$.

\section{Abbreviations}

HSK: herpes simplex keratitis; HSV: herpes simplex virus; slgA: secretory immunoglobulin A. ELISA: enzymelinked immunosorbent assay. PCR: Polymerase chain reaction

\section{Declarations}

\section{Ethics approval and consent to participate}

Ethics approval for the use of human subjects was obtained from the research ethics committee of EYE and ENT hospital, and informed consent was obtained from each patient.

All methods were carried out in accordance with relevant guidelines and regulations. 


\section{Consent for publication}

Not applicable

\section{Availability of data and materials}

All data generated or analyzed during this study are included in this published article and related files.

\section{Competing interests}

The authors declare that they have no competing interests

\section{Funding}

This work was financially supported by Shanghai Committee of Science and Technology Foundation (19441901000).

\section{Authors' contributions}

FF analyzed the patient clinical data, ELISA results and PCR results, and was a major contributor in writing the manuscript. ZJ assayed the tear HSV-sIgA by ELISA. WJ assayed the serum HSV $\operatorname{lgG} / \operatorname{lgM} / \operatorname{lgA}$ by ELISA. CH assayed tear HSV-DNA by PCR. CR was responsible for the diagnoses, treatment and follow-up for all participants. All authors read and approved the final manuscript.

\section{Acknowledgements}

Not applicable

\section{References}

1. Azher TN, Yin XT, Tajfirouz D, Huang A. Herpes simplex keratitis: challenges in diagnosis and clinical management. Clin Ophthalmol. 2017; 11: 185-91.

2. Farooq AV, Shukla D. Herpes simplex epithelial and stromal keratitis: an epidemiologic update. Surv Ophthalmol. 2012; 57: 448-62.

3. Herpetic Eye Disease Study Group. Acyclovir for the prevention of recurrent herpes simplex virus eye disease. N Engl J Med. 1998; 339: 300-6.

4. Herpetic Eye Disease Study Group. Oral acyclovir for herpes simplex virus eye disease: effect on prevention of epithelial keratitis and stromal keratitis. Arch Ophthalmol. 2000; 118: 1030-36.

5. Sudesh S, Laibson PR. The impact of the herpetic eye disease studies on the management of herpes simplex virus ocular infections. Curr Ophthalmol. 1999; 10: 230-3.

6. P Pramod NP, Dhevahi E, Sudhamathi K, Kannan K, Thyagarajan SP. Tear secretory IgA: evaluation of usefulness as a diagnostic marker in herpetic keratitis. Ocul Immunol Inflamm. 1999; 7: 61-7. 
7. Huang FF, Wang ZJ, Zhang CR. Tear HSV-specific secretory IgA as a potential indicator for recurrent stromal herpes simplex keratitis: a preliminary study. Cornea. 2013; 32: 987-91.

8. Shoji J, Sakimoto T, Inada N, Kamei Y, Matsubara M, Takamura E, Sawa M. A diagnostic method for herpes simplex keratitis by simultaneous measurement of viral DNA and virus-specific secretory IgA in tears: an evaluation. JPN J Ophthalmol. 2016; 60: 294-301.

9. Qiu J, Huang F, Wang Z, Zhang CR. The evaluation of diagnostic efficiency for stromal herpes simplex keratitis by the combination of tear HSV-slgA and HSV-DNA. Graefes Arch Clin Exp Ophthalmol. 2017; 255: 1409-15.

10. Tsatsos M, MacGregor C, Athanasiadis I, Moschos M, Hossain P, Anderson D. Herpes simplex virus keratitis: an update of the pathogenesis and current treatment with oral and topical antiviral agents comment. Clin Exp Ophthalmol. 2017; 45: 932.

11. Herpetic Eye Disease Study Group. Psychological stress and other potential triggers for recurrences of herpes simplex virus eye infections. Arch Ophthalmol. 2000; 118: 1617-25.

12. Herpetic Eye Disease Study Group. Predictors of recurrent herpes simplex virus keratitis. Cornea. 2001; 20: 123-8.

13. Uchoa UB, Rezende RA, Carrasco MA, Rapuano CJ, Laibson PR, Cohen EJ. Long-term acyclovir use to prevent recurrent ocular herpes simplex virus infection. Arch Ophthalmol. 2003; 121: 1702-4.

14. Rousseau A, Boutolleau D, Titier K, Bourcier T, Chiquet $C$, Weber $M$, et al. Recurrent herpetic keratitis despite antiviral prophylaxis: A virological and pharmacological study. Antiviral Res. 2017; 146: 20512.

15. Lairson DR, Begley CE, Reynolds TF, Wilhwlmus KR. Prevention of herpes simplex virus eye disease: a cost-effectiveness analysis. Arch Ophthalmol. 2003; 121: 108-12.

16. Satpathy G, Mishra AK, Tandon R, Sharma M, Sharma A, Nayak N, et al. Evaluation of tear samples for Herpes Simplex Virus 1 (HSV) detection in suspected cases of viral keratitis using PCR assay and conventional laboratory diagnostic tools. Br J Ophthalmol. 2011; 95: 415-8.

17. Ma JX, Wang LN, Zhou RX, Yu Y, Du TX. Real-time polymerase chain reaction for the diagnosis of necrotizing herpes stromal keratitis. Int J Ophthalmol. 2016; 9: 682-6.

18. Herpetic Eye Disease Study Group. Predictors of recurrent herpes simplex virus keratitis. Cornea. 2001; 20: 123-8.

19. Kim GN, Yoo WS, Park MH, Chung JK, Han YS Chung IY, et al. Clinical Features of Herpes Simplex Keratitis in a Korean Tertiary Referral Center: Efficacy of Oral Antiviral and Ascorbic Acid on Recurrence. Korean J Ophthalmol. 2018; 32: 353-60.

\section{Figures}




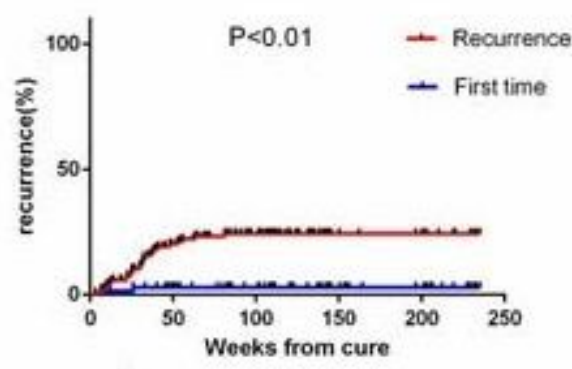

A

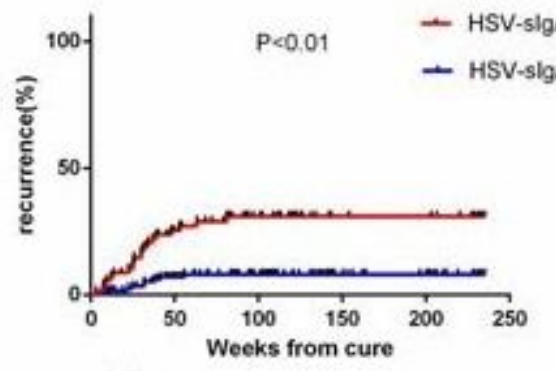

B

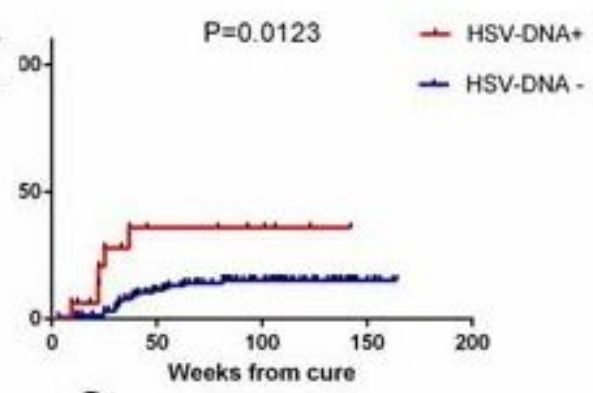

$\mathrm{C}$

\section{Figure 1}

A, Kaplan-Meier analysis for relapse in stromal keratitis patients with episodes (first time or recurrence); B, Kaplan-Meier analysis for relapse in stromal keratitis patients with tear HSV-slgA positivity and negativity; C, Kaplan-Meier analysis for relapse in stromal keratitis patients with tear HSV-DNA positivity and negativity.

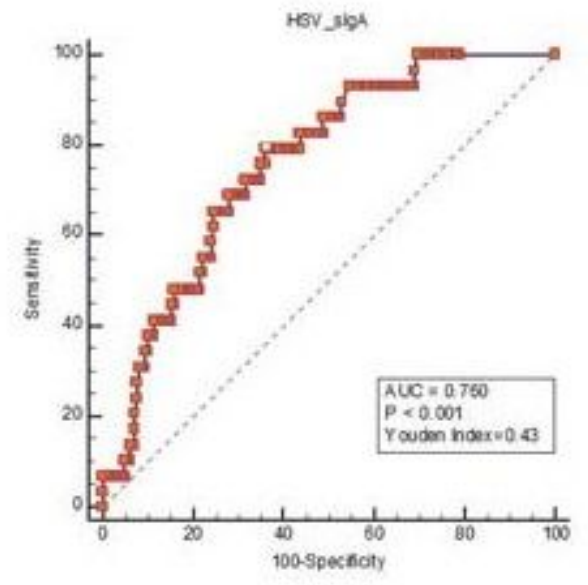

A

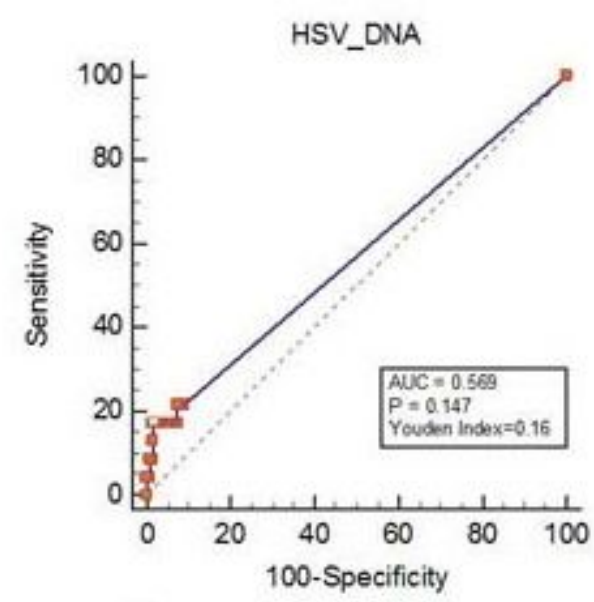

B

Figure 2

Receiver operator characteristic curve analysis for recurrence predictive power of tear HSV-slgA and tear HSV-DNA. 